\title{
AN EPIDEMIOLOGICAL STUDY OF BYSSINOSIS AMONG LANCASHIRE COTTON WORKERS
}

\author{
BY \\ R. S. F. SCHILLING, J. P. W. HUGHES, I. DINGWALL-FORDYCE, and J. C. GILSON \\ From the Nuffield Department of Occupational Health, University of Manchester, and the \\ Medical Research Council Pneumoconiosis Research Unit, Cardiff
}

(RECEIVED FOR PUBLICATION FEBRUARY 27, 1955)

Raw cotton is brought to the Lancashire spinning mills in tightly compressed bales. The bales are opened and teased out in the cotton-room. The cotton is then conveyed to the blow-room where some of the dirt and short fibres are removed. In the card-room the cotton is combed by the wire teeth of the carding engines and passed through a series of machines called combers, ${ }^{*}$ draw, slubbing, intermediate, and roving frames which draw it out into a thin strand (" roving") ready for spinning.

These preparatory processes are dusty and give rise to a respiratory disease called byssinosis. All men who work in the cotton- and blow-rooms are exposed to dust, but the strippers and grinders who clean and sharpen the teeth of the carding engines are probably most exposed. The carder (foreman), the under-carder, the card setter and fitter, and the women "tenters" who mind the various machines in the card-room do not do very dusty work but are exposed to dust emitted from the carding engines. All who work in these rooms come within the provisions of the byssinosis compensation scheme. The spinners, working in the mule- and ring-rooms, which are not very dusty, are not eligible for compensation.

The disease has a characteristic history. At first the worker notices tightness of the chest and breathlessness on Mondays or on the first day back at work after an absence. On the next day he has recovered completely. These symptoms may get worse and occur on Tuesdays and then on all working days. Eventually there is severe and permanent disability.

Greenhow (1861) and Leach (1863) described the disease nearly a hundred years ago and emphasized its serious effects on the health of card-room workers. But the first measurement of its effects was given by the Registrar-General in his report for 1910-12 (published in 1923), when the death

*. Used only in fine spinning. rates for strippers and grinders were given separately from other cotton workers and showed a considerable excess from respiratory disease. Collis (1909) examined 126 strippers and grinders from mills in Blackburn and found that nearly threequarters of them were suffering from an asthmatic condition due to the inhalation of dust. Bradford Hill's statistical study of sickness among cotton workers in the period 1923-27 confirmed that strippers and grinders over 30 and female card-room workers over 25 years of age suffered excessively from respiratory disease but the excess was less for the women than for the men (Bradford Hill, 1930).

After 1920 many mills attempted with some success to reduce dust in card-rooms. Stripping brushes for cleaning the teeth of carding engines were enclosed and exhausted, carding engines vacuum cleaned, and card-rooms air-conditioned. The Departmental Committee on Dust in Card-rooms (Home Office, 1932) concluded from medical and other evidence that although some ill-health was still caused by the dust, it was not so marked since these improvements had been made.

The Departmental Committee on Compensation for Card-Room Workers (Home Office, 1939) found that in 1935-36 male card-, blow-, and cotton-room workers still suffered from an excess of respiratory sickness compared with spinners and weavers ; but the excess among the card-room workers appeared to be less than that reported earlier by Bradford Hill. On the recommendation of this committee a compensation scheme for byssinosis was started in 1940 for totally incapacitated men who had worked for at least 20 years in the dusty rooms. The scheme now includes women, and pensions are payable for disabilities assessed at $50 \%$ and over. In the period 1951-53, 150 new pensions were granted for byssinosis (Ministry of Pensions and National Insurance, 1952, 1953, and 1954). Compensation figures are notoriously unreliable indices 217 
of the prevalence of any industrial disease (Cochrane, 1951) and these figures certainly underestimate the prevalence of byssinosis. First, they include only seriously disabled workers. Secondly, this disease is often thought by many workers and doctors to be the "chronic bronchitis" which occurs so frequently in the general population of Lancashire (Goodman, Lane, and Rampling, 1953).

Unlike the pneumoconioses caused by mineral dusts there are no specific $x$-ray changes. The aetiology is obscure since the causative agent and its mode of action are unknown. The one recorded study of the pathology by Shaw Dunn and Sheehan (1932) does not shed any light on aetiology or help in diagnosis at necropsy, since they found chronic bronchitis and emphysema which was in no way specific in type.

It was decided first of all to find out if byssinosis is still a major problem in the Lancashire cotton industry. It was thought that it might be, since a recent study revealed that chronic chest disease overshadowed all others in middle-aged cotton workers employed in the dusty trades (Schilling, Goodman, and O'Sullivan, 1952).

The study described in this paper was made in a large group of Lancashire mills spinning the coarser grades of raw cotton. They were chosen because they are said to be dustier than mills spinning finer grades and to have a higher prevalence of byssinosis (Collis, 1909). The field work was undertaken between February and December, 1953, and between November and December, 1954. The reliability of the diagnosis in byssinosis has been investigated by Schilling, Hughes, and Dingwall-Fordyce (1955) and found to be sufficiently good to enable a reasonably accurate estimate of prevalence to be made. This paper reports the prevalence in male card- and blow-room workers, mule spinners, female card-room workers, and ring spinners; and also the severity of disability caused by the disease.

\section{PROCEDURE}

\section{Mills and Populations Studied}

In Oldham and the neighbouring towns of Shaw, Middleton, and Chadderton there are 112 mills spinning the coarser grades of raw cotton. Twentyeight were selected as those which were most likely to cooperate.*

Men aged between 40 and 59 years in the cardand blow-rooms $\dagger$ were the first population

\footnotetext{
* A random sample might well have included mills which would not have cooperated, thus causing high refusal rates. As will be seen later, there is no reason to believe that the mills visited were not later, there is no reason to believe that the mills visited
representative of all the mills in the prevalence of respiratory disease. t Cotton-room workers were not included because there are very
few of them and they do not usually remain in this job for long.
}

studied. There was a total of 202 of these men in the 28 mills; 12 men were excluded for various reasons (Table 1) and the final analysis of results was made on 190 .

TABLE 1

POPULATIONS OF MALE COTTON WORKERS AND CONTROLS AGED 40-59 YEARS

\begin{tabular}{|c|c|c|}
\hline & $\begin{array}{l}\text { Male Card- and } \\
\text { Blow-room } \\
\text { Workers }\end{array}$ & $\begin{array}{l}\text { Factory Workers } \\
\text { (Controls) }\end{array}$ \\
\hline 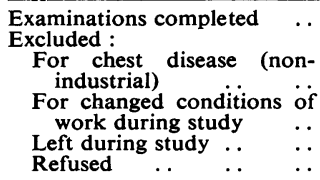 & $\begin{array}{l}2^{*} \\
\frac{5}{5}\end{array}$ & $\begin{array}{c}3 \dagger \\
-5 \\
4\end{array}$ \\
\hline Total .. & 202 & 100 \\
\hline
\end{tabular}

* One man extensive fibrosis in left upper zone. One man fibrosis right upper zone with cavity.

$\dagger$ One man active tuberculous lesion in right upper zone. One man pleural effusion at left base. One man extensive pleurisy.

For comparison a group of men of similar ages to the cotton workers but who had never worked in card- and blow-rooms was examined. Two engineering factories in the Oldham district provided these controls, 100 men in all consisting of the total population between 40 and 60 years from one factory, and a random sample of the total population of this age from the other. They were skilled or semi-skilled manual workers and their foremen and had not been exposed to any recognized hazard causing industrial pulmonary disease. Twelve men were excluded for various reasons (Table 1) and the final analysis was made on 88 .

TABLE 2

POPULATIONS OF WOMEN CARD- AND RING-ROOM WORKERS AND MALE MULE SPINNERS, AGED 40-59, AT RISK IN 6 MILLS

\begin{tabular}{ccc|c|c|c|c}
\hline & & \multicolumn{2}{|c|}{ Women } & Men \\
\cline { 3 - 6 } & & $\begin{array}{c}\text { Card-room } \\
\text { Workers }\end{array}$ & $\begin{array}{c}\text { Ring-room } \\
\text { Workers }\end{array}$ & $\begin{array}{c}\text { Mule } \\
\text { Spinners }\end{array}$ \\
\hline Examinations completed & $218(97 \%)$ & $61(95 \%)$ & $62(89 \%)$ \\
Excluded.. &. &.. & 5 & 2 & 4 \\
Refused.. &.. &.. & 3 & 1 & 4 \\
\hline Total &.. &.. & 226 & 64 & 70 \\
\hline
\end{tabular}

After these men had been seen and the results analysed, groups of women card- and ring-room workers and male mule spinners from six of the 28 mills were examined in less detail to complete the epidemiological picture of byssinosis. The populations at risk and the numbers seen are given in Table 2.

\section{Examinations}

For the male card- and blow-room workers postero-anterior radiographs of the chest in 
inspiracion and expiration and a lateral radiograph were first taken using full-sized films. Later these men were examined at their place of work on two separate occasions on working days other than Mondays and Fridays. Two examinations were made (in all but seven of the men) to determine the reliability of the signs and symptoms of byssinosis. At the first an occupational history and notes of previous illnesses were recorded and detailed questions asked about chest complaints. The chest was then examined clinically and the blood pressure recorded. At the second examination made about four months later the questions about chest complaints and the clinical examinations were repeated by the other observer who had no knowledge of the previous results except the occupational history and the record of previous illnesses.

The volume of gas expelled during the first 0.75 sec. of a forced expiration was measured by a modified Gaensler (1951) apparatus. Five readings were taken and the results calculated from the mean of the three highest (correct to B.T.P.). Tiffeneau, Bousser, and Drutel (1949) have used this test as an indirect measure of maximum breathing capacity. Kennedy (1953) called this measurement the "expiratory flow rate" (E.F.R.) and showed it correlated very highly with the maximum voluntary ventilation measured directly. We have expressed our results in litres per min. as described by Kennedy but prefer Tiffeneau's terminology (indirect M.V.V.) The close correlation between the maximum breathing capacity measured directly (at a fixed rate of breathing) and that derived indirectly from the volume of gas expelled during a single fast expiration has been confirmed by Bernstein and Kazantzis (1954).

\section{DIAGNOSIS OF BYSSINOSIS}

\section{History}

Each observer classified the men on their clinical histories as follows :

\footnotetext{
Normal: No symptoms of chest tightness or breathlessness on Mondays

Byssinosis :

Grade I Chest tightness and/or breathlessness on Mondays only

Grade II Chest tightness and/or breathlessness on Mondays and other days
}

Both observers examined 183 cotton workers and made the same diagnosis in $139(76 \%)$. After consultation the diagnosis was agreed in $20(11 \%)$ more. In six men the observers continued to disagree on the presence or absence of byssinosis (see Table 3).

\section{Physical Signs}

The disagreement between the observers on the detection of physical signs normally accepted as being associated with emphysema, such as absent apical impulse and chest fixity, was too great to add much to the precision of the diagnosis of byssinosis (Schilling, Hughes, and Dingwall-Fordyce, 1955). Thus the results of the clinical examinations of the chest are not included in this paper.

Blood pressures, which will be discussed in another paper, were not on the average significantly higher in the card- and blow-room workers than in the controls, as was found previously (Schilling and others, 1952).

Radiographs. - In a study of byssinosis 20 years ago Fletcher found changes in the lung fields consistent with chronic bronchitis and some degree of emphysema, but he thought that there was some excess of the root and bronchial shadows of a degree not seen in ordinary bronchitis (Prausnitz, 1936). In our study the radiographs of three samples of 15 men each were chosen : cotton workers with Grade II byssinosis, normal cotton workers, and normal controls. All were matched for age and no one with a history of another respiratory disease was included. These films were studied by one of the authors (J. C. G.) with Dr. A. L. Cochrane. Although these readers knew from which group the films came they were unable to detect any striking differences between them. Thus radiographs did not assist in diagnosis. The only difference noted was a smaller excursion of the diaphragm on comparing inspiratory and expiratory films. The average excursion of the byssinotics was $3.28 \mathrm{~cm}$. compared with $4.55 \mathrm{~cm}$. for the other two groups together. The difference is significant at the $2 \%$ level.

The diagnosis of byssinosis, therefore, depended on the worker's account of his symptoms. It would have been preferable if the diagnosis had been made without the observer knowing the man's occupation in the mill but this was rarely possible because discussion of his symptoms usually revealed where he worked. The consistency of the histories and the agreement between the gradings of byssinosis and the test of ventilatory capacity (discussed later) are evidence in support of the reliability of the assessments. The discovery of cases of byssinosis in ring-room workers and mule spinners where it was not expected suggests that the results are not biased towards an over-estimate of its prevalence elsewhere.

Chronic bronchitis was diagnosed on a history of persistent cough with sputum in the absence of other respiratory disease. The inter-observer reliability 
was not measured, as cases were diagnosed only after joint discussion of the histories obtained by both observers.

\section{RESULTS}

MALE CARD- AND BLOW-ROOM WORKERS

Altogether $115(60 \%)$ of the male card- and blowroom workers gave a clinical history of byssinosis (Table 3). In 24 men in whom the observers failed to agree on the diagnosis of byssinosis the less favourable diagnosis was chosen.

TABLE 3

PREVALENCE OF BYSSINOSIS IN 190 MALE CARD- AND BLOW-ROOM WORKERS

\begin{tabular}{|c|c|c|c|c|c|}
\hline & \multicolumn{2}{|c|}{ Observers Agreed } & \multirow{2}{*}{$\begin{array}{l}\text { Observers } \\
\text { Disagreed }\end{array}$} & \multirow{2}{*}{$\begin{array}{c}\text { Examined } \\
\text { Once }\end{array}$} & \multirow[b]{2}{*}{ Total } \\
\hline & Initially & $\begin{array}{l}\text { After Con- } \\
\text { sultation }\end{array}$ & & & \\
\hline Normal $\ldots$ & 72 & 1 & - & 2 & 75 \\
\hline$\underset{\text { Byssinosis }}{\text { Grade II }}$ & 47 & 11 & 6 & 3 & $\begin{array}{c}67 \%) \\
67 \%) \\
(35 \%)\end{array}$ \\
\hline $\begin{array}{l}\text { Grade II } \\
\text { Byssinosis }\end{array}$ & 20 & 8 & 18 & 2 & $\begin{array}{l}48 \\
(25 \%)\end{array}$ \\
\hline Total & 139 & 20 & 24 & 7 & 190 \\
\hline
\end{tabular}

A typical case history for each grade of byssinosis is given in Appendix I.

Among the men graded as normal there were 15 who told both observers that they had noticed other symptoms, particularly on Mondays. These symptoms and the number of times they were recorded were : cough (8); irritation of respiratory tract by smoke (5) ; breathing more difficult on Monday but not amounting to tightness (2); headache (1) ; feeling feverish (1) ; and fatigue (1). These symptoms appear to be early or mild manifestations of the disease. Among the 88 controls none complained of tightness of the chest or breathlessness on Mondays; one of the 12 men diagnosed as having chronic bronchitis told one observer that his breathing was worse on Mondays.

\section{Occupation}

By allocating men to the occupation in which they had spent more than $50 \%$ of their time it was possible to compare the prevalence of disease in four groups: (1) Carders and under-carders ; (2) card setters and fitters, cotton-room men, ${ }^{*}$ and men with a mixed occupational history; (3) strippers and grinders ; (4) blow-room workers.

Table 4 shows that $65 \%$ of the strippers and grinders and the blow-room workers had byssinosis and $42 \%$ of the carders and under-carders and the others were affected. This supports the view that the strippers and grinders and blow-room workers are exposed to more dust than the other men in the card-room.

\section{Disability by Clinical Assessment}

Respiratory disability was first assessed on the clinical grading of dyspnoea.

Since breathlessness which varies from day to day is a characteristic feature of byssinosis, it was graded for the men's best and worst days as follows :

Normal I : Able to keep up with normal men of own age on hills.

Slight II : Only able to keep up with normal men of own age on the level.

Mcderate III : Unable to do the above but can walk about a mile at own speed without stopping.

Severe IV: Only able to walk about a hundred yards without stopping.

, $\quad V:$ Unable to do the above.

Table 5 shows that the cotton workers have more temporary and permanent effort intolerance than the controls; the strippers and grinders and blowroom workers (Group B) having more than the other cotton workers (Group A).

\section{Disability by Spirometric Assessment}

As the assessment of respiratory disability by dyspnoea grading is liable to a relatively large observer error (Schilling and others, 1955), the results of the more objective maximum voluntary ventilation measurement are of interest. Like other

* These men, although now employed in card- and blow-rooms, have been allocated to the cotton-room because they had spent more than $50 \%$ of their time there.

TABLE 4

PREVALENCE OF BYSSINOSIS IN VARIOUS OCCUPATIONS IN CARD- AND BLOW-ROOMS

\begin{tabular}{|c|c|c|c|c|c|c|c|c|c|c|}
\hline \multirow{2}{*}{\multicolumn{4}{|c|}{ Group }} & \multirow{2}{*}{ Number } & \multirow{2}{*}{ Mean Age } & \multirow{2}{*}{$\underset{\substack{\text { Mean } \\
\text { Exposure } \\
\text { (years) }}}{2}$} & \multirow{2}{*}{ Normal } & \multicolumn{2}{|c|}{ Byssinosis } & \multirow{2}{*}{$\begin{array}{l}\text { Percentage } \\
\text { Affected }\end{array}$} \\
\hline & & & & & & & & I & II & \\
\hline Carders and $U /$ carders & $A$ & . & . & 21 & $48 \cdot 6$ & $23 \cdot 2$ & 12 & 5 & 4 & \\
\hline Others * & $n$ & . & . & 19 & $47 \cdot 1$ & $23 \cdot 2$ & 11 & 5 & 3 & \\
\hline Strippers and grinders & & .. & . & 112 & $48 \cdot 7$ & $22 \cdot 8$ & 39 & 46 & 27 & (E, \\
\hline Blow-room & $\mathbf{D}$ & . & .. & 38 & $50 \cdot 6$ & 25.9 & 13 & 11 & 14 & $000 \%$ \\
\hline
\end{tabular}

* 10 card setters and fitters, 6 cotton-room men, 3 mixed.

Proportionately more blow-room workers than strippers and grinders were seriously affected, perhaps because they were on the average older men with longer exposures. 
TABLE 5

DYSPNOEA GRADINGS AMONG 186 MALE COTTON WORKERS AND 88 CONTROLS

\begin{tabular}{|c|c|c|c|c|c|c|c|c|c|c|}
\hline \multicolumn{5}{|c|}{ Dyspnoea Grading } & \multicolumn{3}{|c|}{$\begin{array}{c}\text { On Best Days } \\
\text { (Permanent Disability) }\end{array}$} & \multicolumn{3}{|c|}{$\begin{array}{c}\text { On Worst Days } \\
\text { (Temporary Disability) }\end{array}$} \\
\hline & & & & & $\begin{array}{c}\text { Controls } \\
\mathbf{8 8}\end{array}$ & $\underset{39}{\text { Group } A}$ & $\underset{147}{\text { Group B }}$ & $\begin{array}{c}\text { Controls } \\
88\end{array}$ & $\underset{39}{\text { Group } A}$ & $\underset{147}{\text { Group } B}$ \\
\hline $\begin{array}{l}\text { Normal I } \\
\text { Slight II } \\
\text { Moderate III } \\
\text { Severe IV } \\
\text { ". }\end{array}$ & $\begin{array}{l}\cdots \\
\cdots \\
\cdots \\
\cdots\end{array}$ & $\begin{array}{l}\cdots \\
\cdots \\
\cdots\end{array}$ & $\begin{array}{l}\cdots \\
\cdots \\
\cdots\end{array}$ & $\begin{array}{l}\cdots \\
\cdots \\
\cdots\end{array}$ & $\begin{array}{c}90 \% \\
10 \% \\
= \\
-\end{array}$ & $\begin{array}{r}82 \% \\
13 \% \\
5 \% \\
-\end{array}$ & $\begin{array}{r}63 \% \\
28 \% \\
8 \% \\
1 \% \\
-\end{array}$ & $\begin{array}{c}85 \% \\
14 \% \\
1 \% \\
-\end{array}$ & $\begin{array}{r}65 \% \\
18 \% \\
10 \% \\
6 \% \\
\end{array}$ & $\begin{array}{r}49 \% \\
22 \% \\
19 \% \\
9 \% \\
2 \%\end{array}$ \\
\hline Excluded * .. & $\cdots$ & $\cdots$ & $\cdots$ & $\cdots$ & - & 1 & 3 & - & 1 & 3 \\
\hline
\end{tabular}

* Four cotton workers were excluded for the following reasons : Arthrodesis left knee, intermittent claudication, ? carcinoma of stomach, mitral incompetence.

The observers agreed exactly in their gradings on the best days for $65 \%$ of cotton workers and $88 \%$ of the controls. The corresponding figures for the worst days were $58 \%$ and $88 \%$. Where there was a disagreement the mean of the observers' gradings was taken. Of the men who had grades of $2 \frac{1}{2}, 3 \frac{1}{2}$, and $4 \frac{1}{2}$ half were allocated to the higher and half to the lower grade.

physiological tests it demands cooperation from the subject but in this study cooperation was, almost without exception, excellent. This is supported by the close repeatability of values obtained on the same subjects in these factories and mills over a period of several months, using more than one observer. The standard error of an estimate of the maximum voluntary ventilation was $6 \cdot 31 . / \mathrm{min}$. Figure 1 and Table 6 show that the cotton workers without byssinosis, age for age, have an average M.V.V. very similar to that of the controls. Men with Grade II byssi-

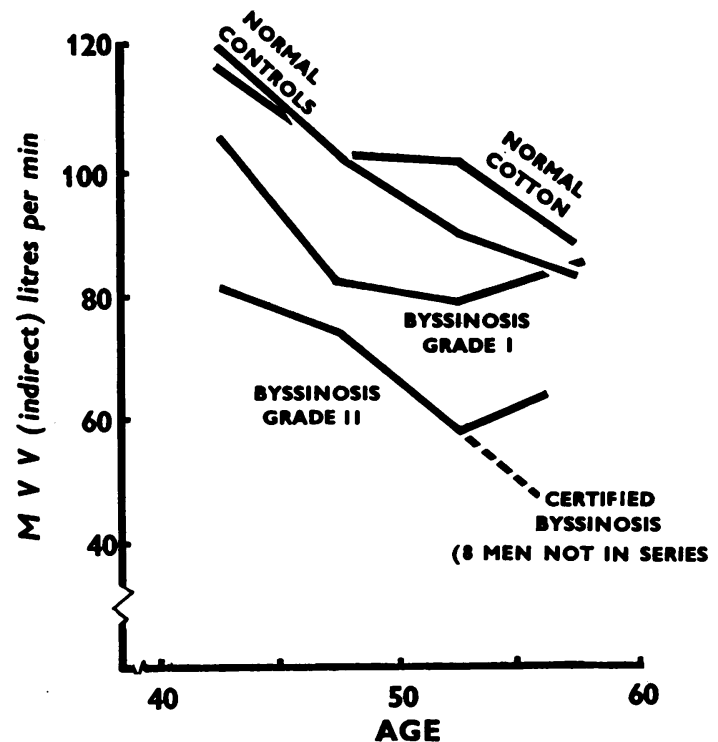

FIG. 1.-The timed vital capacity expressed as " indirect" M.V.V. (1./min.) in cotton workers and normal controls, and eight men certified as suffering from byssinosis and not working. (These differences between men with byssinosis and normals could be due to these groups being anthropometrically different. This is very unlikely since their mean chest circumferences (in expiration) were almost identical.) nosis have average values lower than men with Grade I byssinosis. Also, men with Grade I byssinosis have average values significantly lower than normal. This is of interest since these men complained of breathlessness on Mondays only and all the tests were done on other days.

Since all the cotton workers were working they were a selected population, those with severe

TABLE 6

TIMED VITAL CAPACITIES EXPRESSED AS MAXIMUM VOLUNTARY VENTILATION (INDIRECT) IN LITRES/MIN. OF COTTON WORKERS AND CONTROLS

\begin{tabular}{|c|c|c|c|c|c|}
\hline \multirow{2}{*}{ Age } & \multicolumn{3}{|c|}{ Cotton Workers } & \multicolumn{2}{|c|}{ Controls } \\
\hline & Normal & Grade I & Grade II & Normal & Bronchiti; \\
\hline $\begin{array}{l}\text { Mean } \\
\text { 40-44 S.D. } \\
\text { No. }\end{array}$ & $\begin{array}{c}117 \dagger \\
20 \cdot 1 \\
27\end{array}$ & $\begin{array}{c}106 \dagger \\
18 \cdot 9 \\
16\end{array}$ & $\begin{array}{l}\{1 \\
30 \\
12\end{array}$ & $\begin{array}{c}121 \\
21 \cdot 8 \\
31\end{array}$ & $\begin{array}{c}105 / 124 \\
2\end{array}$ \\
\hline $\begin{array}{l}\text { Mean } \\
\text { 45-49 } \begin{array}{l}\text { S.D. } \\
\text { No. }\end{array}\end{array}$ & $\begin{array}{c}103^{*} \\
19 \cdot 1 \\
22\end{array}$ & $\begin{array}{l}82 * \\
29 \cdot 2 \\
22\end{array}$ & $\begin{array}{l}74 \\
21 \cdot 5 \\
11\end{array}$ & $\begin{array}{l}103 \\
25 \cdot 1 \\
15\end{array}$ & $\begin{array}{c}67 / 115 \\
2\end{array}$ \\
\hline $\begin{array}{ll}\text { Mean } & \\
\text { 50-54 } & \begin{array}{l}\text { S.D. } \\
\text { No. }\end{array}\end{array}$ & $\underset{9}{102 \dagger} \cdot$ & $\begin{array}{l}7 s * \dagger \\
26 \cdot 9 \\
18\end{array}$ & $\begin{array}{l}58^{*} \\
26 \cdot 3 \\
14\end{array}$ & $\begin{array}{l}90 \\
19 \cdot 8 \\
17\end{array}$ & $\begin{array}{c}78 / 80 \\
2\end{array}$ \\
\hline $\begin{array}{l}\text { Mean } \\
\text { 55-59.D. } \\
\text { No. }\end{array}$ & $\begin{array}{l}88 \dagger \\
16 \cdot 4 \\
15\end{array}$ & $\begin{array}{l}85 \\
20 \cdot 2 \\
10\end{array}$ & $\begin{array}{l}66 \dagger \\
26.0 \\
11\end{array}$ & $\begin{array}{c}83 \\
14 \cdot 3 \\
9\end{array}$ & $\begin{array}{c}64 \\
28 \cdot 8 \\
6\end{array}$ \\
\hline
\end{tabular}

Three cotton workers and four controls were not available for this test.

* Significant difference $P<0.01$.

† Significant difference $P<0.05$.

byssinosis or other illnesses having been obliged to leave the trade. Such a process of selection probably explains the relatively high M.V.V. of the older men with byssinosis. Eight men receiving disability pensions for byssinosis but not belonging to this group were found to have a low M.V.V.* Of the 12 controls with bronchitis, eight had lower values than the normal men, but some did not complain of any effort intolerance.

* The mean age of these men was 55.9 , and their mean M.V.V. was 47.3 1./min. (see Fig. 1). 
A pilot study had shown that the results of this test differed on Monday from other days of the week but not between other days within the same week. After the main investigation the extent of the temporary disability on Mondays was assessed by measuring the M.V.V. of 46 cotton workers and 24 controls twice, first on a Thursday and then on the following Monday. The two groups with byssinosis show a highly significant reduction in M.V.V. on Mondays (Table 7 and Fig. 2), although the change in absolute values is not large. The normal cotton workers and the controls showed no significant change between Monday and Thursday.

TABLE 7

PROPORTIONAL CHANGE IN MAXIMUM VOLUNTARY VENTILATION (INDIRECT) ON MONDAYS

\begin{tabular}{|c|c|c|c|c|}
\hline Group & $\begin{array}{c}\text { No. } \\
\text { of } \\
\text { Men }\end{array}$ & $\begin{array}{c}\text { Mean of } \\
\text { M.V.V.s (1./min.) } \\
\text { on Mon./Thurs. } \\
\times 100\end{array}$ & $\begin{array}{l}\text { S.E. } \\
\text { of } \\
\text { Mean }\end{array}$ & $\begin{array}{c}\text { Significance of } \\
\text { Proportional } \\
\text { Decrease on } \\
\text { Monday }\end{array}$ \\
\hline $\begin{array}{l}\text { Controls } \\
\text { Cotton workers }\end{array}$ & 24 & $100 \%$ & $1 \cdot 1$ & - \\
\hline$\underset{\text { Grade I }}{\text { normal }} \cdots$ & 13 & $97 \%$ & $2 \cdot 1$ & $P=0.1 \quad(t=1 \cdot 3)$ \\
\hline $\begin{array}{l}\text { byssinosis } \\
\text { Grade II }\end{array}$ & 22 & $91 \%$ & $2 \cdot 1$ & $P<0.0005(t=4.0)$ \\
\hline byssinosis & 11 & $90 \%$ & $2 \cdot 0$ & $\mathrm{P}<0.0005(\mathrm{t}=4.7)$ \\
\hline
\end{tabular}

CONTROLS
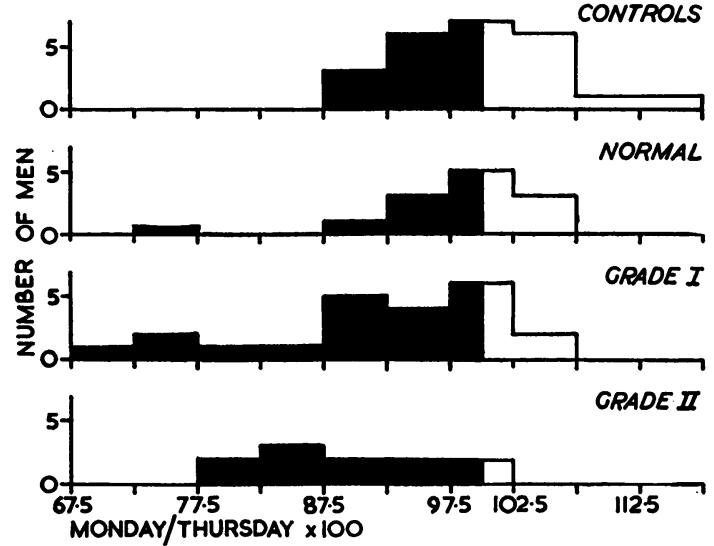

FIG. 2.-Change in M.V.V. on Mondays compared with Thursdays.

The Severely Disabled Men

Thirteen cotton workers were considered to be seriously disabled because of the severity of their Monday symptoms and dyspnoea on their best days. All but two of them had an M.V.V. below the means for their ages (Table 8).

A maximum voluntary ventilation of less than 50 $1 . / \mathrm{min}$. indicates quite severe respiratory disability in men of this age. There were 13 cotton workers, excluding the five in Table 8 , who had byssinosis and an M.V.V. of less than $501 . / \mathrm{min}$. Four controls (three with bronchitis) also had M.V.V.s below this level.
TABLE 8

COTTON WORKERS SEVERELY DISABLED WITH BYSSINOSIS (GRADE II)

\begin{tabular}{|c|c|c|c|c|c|}
\hline \multirow{2}{*}{ Patient } & \multirow{2}{*}{$\begin{array}{l}\text { Mean Grade } \\
\text { Dyspnoea on } \\
\text { Best Days }\end{array}$} & \multicolumn{2}{|c|}{ M.V.V. (1./min.) } & \multirow{2}{*}{$\begin{array}{c}\text { Exposure } \\
\text { to Cotton } \\
\text { (years) }\end{array}$} & \multirow{2}{*}{ Occupation } \\
\hline & & Observed & Expected $\dagger$ & & \\
\hline M.G.* & 4 & 39 & 80 & 39 & \\
\hline $\begin{array}{l}\text { H.J.H. } \\
\text { C.J. }\end{array}$ & $\begin{array}{l}3 \cdot 5 \\
3 \cdot 5\end{array}$ & $\begin{array}{l}87 \\
24\end{array}$ & $\begin{array}{l}70 \\
80\end{array}$ & $\begin{array}{l}30 \\
28\end{array}$ & \\
\hline $\begin{array}{l}\text { H.B.** } \\
\text { B.L.* }\end{array}$ & $\begin{array}{l}3 \\
3\end{array}$ & $\begin{array}{l}78 \\
75\end{array}$ & $\begin{array}{l}89 \\
87\end{array}$ & $\begin{array}{l}35 \\
31\end{array}$ & $\begin{array}{l}\mathrm{g} \\
\mathrm{Car} \\
\text { Stri }\end{array}$ \\
\hline D.V. & 3 & 72 & 89 & 30 & Stri \\
\hline $\begin{array}{l}\text { F.M.M.* } \\
\text { S.J.** } \\
\text { C.H. }\end{array}$ & $\begin{array}{l}3 \\
3 \\
3\end{array}$ & $\begin{array}{l}25 \\
36 \\
82\end{array}$ & $\begin{array}{l}87 \\
94 \\
70\end{array}$ & $\begin{array}{l}27 \\
29 \\
35\end{array}$ & $\begin{array}{l}\text { gro } \\
\text { Blow } \\
\text { Blow } \\
\text { Strip }\end{array}$ \\
\hline R.F. & $2 \cdot 5$ & 51 & 80 & 38 & Strip \\
\hline B.T.* & $2 \cdot 5$ & 81 & 97 & 21 & $\begin{array}{l}\text { grinder } \\
\text { Stripper and }\end{array}$ \\
\hline $\begin{array}{l}\text { W.G.** } \\
\text { E.J. }\end{array}$ & $\begin{array}{l}2 \cdot 5 \\
2 \cdot 5\end{array}$ & $\begin{array}{l}29 \\
82\end{array}$ & $\begin{array}{r}78 \\
113\end{array}$ & $\begin{array}{l}34 \\
21\end{array}$ & $\begin{array}{l}\text { Blow-room } \\
\text { Under- } \\
\quad \text { carder }\end{array}$ \\
\hline
\end{tabular}

* These men have since been awarded a $50 \%$ disability pension for byssinosis.

$\dagger$ The expected M.V.V. in which an allowance is made for age was calculated from the regression equation, $y=210 \cdot 8-2 \cdot 4 x$ for all cotton workers and controls, where $\mathrm{y}=$ M.V.V. and $x=$ age.

Altogether there were 26 cotton workers severely disabled with byssinosis; and there were 12 other men not yet seriously disabled who told both observers that their symptoms of byssinosis had definitely got worse during the last 12 months.

\section{Length of Exposure}

Table 9 shows that the prevalence of the disease among the men who have been in the industry at least 20 years is more than twice as high as it is among those who have been in less than 10 years.

TABLE 9

PREVALENCE OF BYSSINOSIS AND LENGTH OF EXPOSURE IN CARD- AND BLOW-ROOMS

\begin{tabular}{c|c|c|c|c}
\hline $\begin{array}{c}\text { Years of } \\
\text { Exposure }\end{array}$ & \multirow{2}{*}{ Normal } & \multicolumn{3}{|c}{ Byssinotics } \\
\cline { 3 - 5 } & & Grade I & Grade II & Total (\%) \\
\hline $\begin{array}{c}0-9 \\
10-19\end{array}$ & 14 & 4 & 3 & 33 \\
$20-29$ & 22 & 18 & 7 & 53 \\
$30+$ & 17 & 22 & 19 & 65 \\
\hline
\end{tabular}

But these figures take no account of the men who have left the industry because of the disease and, therefore, underestimate its true prevalence in relation to exposure. With age * held constant there is no correlation $(r=+0.02)$ between the M.V.V.s and exposure for the cotton workers.

This surprising finding cannot be adequately explained with the small groups available. We think it is probably the result of a high degree of selection

* The correlation between M.V.V. and age with exposure held constant was $r=-0.47$. 
in the population, the more disabled men with a low M.V.V. having left the mills as indicated by Fig. 1 .

It may also be related to the type of response to the dust. It appears that only a proportion of subjects is susceptible at all to this dust and it may be that after a certain stage is reached the condition, and in particular the decline in ventilatory capacity, is progressive in the absence of further exposure. The stage at which this progressive decline takes place may be much more closely related to the age of the subject than to his exposure.

For the disabled men and those who were definitely getting worse, periods of exposure ranged from 18 to 39 years. All but one man, who was slightly disabled and getting worse, had worked in card- or blow-rooms for more than 20 years.

Unfortunately, the disease has such an insidious onset that it is very difficult for men to remember when their symptoms started. Thus it was not possible to calculate reliably each man's period of exposure before the onset of symptoms (induction time). But the induction times of the 58 men who gave the same answers to both observers ranged from less than one year to more than $\mathbf{3 0}$ years with a mean of $16 \cdot 7$.

\section{Chronic Bronchitis}

Men with chronic bronchitis develop tightness of the chest whenever they are exposed to a sufficient concentration of any dust. In the early stages of byssinosis the worker is affected only by cotton dust and only on Mondays. Even in the later stages of the disease Monday is the worst day, although the card-rooms are not dustier on that day (Drummond, Hamlin, Donoghue, and Brownsett, 1954).

The symptom complex of chronic bronchitis is, therefore, not the same as byssinosis.

There were two blow-room workers who had symptoms of chronic bronchitis but not of byssinosis (see Appendix I). As byssinosis progresses the patient often also has symptoms of chronic bronchitis, but it is not an invariable complication. There were 12 men with byssinosis who had a dry cough and 20 who had no cough at all. The added effect of a respiratory infection, such as bronchitis, on the progress of byssinosis will be discussed in a later paper.

\section{Prevalence of Byssinosis in Male Card- and Blow- room Workers in Other Mills}

Since the 28 mills were not a random sample of all the 112 mills in the Oldham area, it is not possible from these results alone to be certain about the general prevalence of the disease in this area. But there are two further sources of information. Seventeen other mills in the Oldham area were studied either previously or in the pilot survey of this inquiry; four mills doing coarse spinning in the Ashton-under-Lyne district have also been recently studied, but not in as great detail.

The proportions of card- and blow-room workers affected with byssinosis are similar in all three groups of mills :

\begin{tabular}{|c|c|c|c|c|}
\hline \multirow{2}{*}{ Group } & \multirow{2}{*}{$\begin{array}{c}\text { Total No. } \\
\text { of Men } \\
\text { (aged 40-59) }\end{array}$} & \multicolumn{3}{|c|}{ No. with Byssinosis } \\
\hline & & I & II & Total \\
\hline $\begin{array}{l}28 \text { mills in Oldham area } \\
17 \% \text { \# \# Ash" }\end{array}$ & $\begin{array}{l}190 \\
107\end{array}$ & $\begin{array}{l}67 \\
33\end{array}$ & $\begin{array}{l}48 \\
23\end{array}$ & $\begin{array}{l}60 \% \\
52 \%\end{array}$ \\
\hline $\begin{array}{llll}\text { district } & \ldots & \ldots & \ldots\end{array}$ & 44 & 17 & 7 & $54 \%$ \\
\hline
\end{tabular}

It thus seems likely that the prevalence figures established for the 28 mills are reasonably representative of all mills doing coarse spinning.

\section{THE WOMEN CARD-ROOM WORKERS AND} THE SPINNERS

A similar procedure was adopted in studying the women card-room workers, but they were not examined clinically and were seen by only one observer. The M.V.V. was not measured. As byssinosis has not been reported previously among spinners, all those (with one exception) who gave a history of the disease were seen by the second observer and Professor R. E. Lane, and were examined clinically and radiographed at the Manchester Royal Infirmary. The observers discussed the case histories of all workers in whom byssinosis was diagnosed and agreed on the recorded diagnosis.

In the card-room the draw and slubber frames are close to the carding engines and the intermediate and roving frames are some distance from them. The results in Table 10 and Fig. 3 show that the prevalence of byssinosis in the card-rooms was less in the workers farther away from the carding engines, and that very few workers in the spinning rooms were affected. This epidemiological pattern was fairly consistent for each of the six mills (see Appendix II). While there is always some movement of women tenters in the card-room from job to job, there were enough card-room tenters who were known to have worked consistently on the same jobs to confirm the validity of these results.

\section{Disability}

As the M.V.V. was not measured in this group it was not possible to assess their disability with equal confidence. But there were 12 (nine working near the carding engines) who had byssinosis and moderate or severe effort intolerance on their best days. None of the ring spinners or mule spinners was thought to be seriously disabled by 


\section{BYSSINOSIS}

GRADE ॥

GRADE I

NORMAL

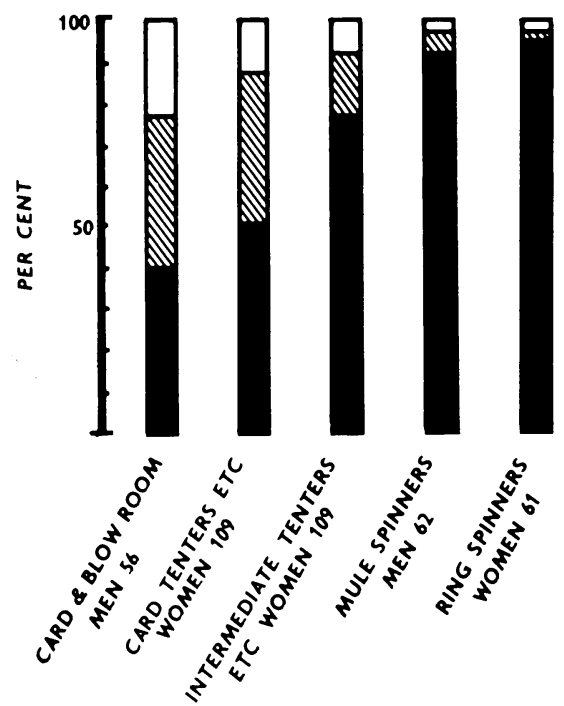

Fig. 3.-Prevalence of byssinosis in the card-room workers and spinners in the six mills.

byssinosis alone. The clinical study of the spinners will be reported in more detail elsewhere.

\section{DISCUSSION}

These results indicate that byssinosis can usually be diagnosed reliably in this type of field research. It does not follow that it can be similarly diagnosed by doctors considering claimants for compensation. A claimant cannot be expected to have the same outlook towards his disease as a participant in a survey. Doctors on medical panels may also examine those who have left the industry and are so disabled and distressed by dyspnoea that they cannot recall that they once had the characteristic Monday symptoms.

The existing compensation scheme (Ministry of National Insurance, 1948) which is now under review limits awards to those with disability assessed at $50 \%$ or more who have worked in the prescribed processes for at least 20 years. These limits, made because of the difficulty of distinguishing byssinosis from bronchitis and emphysema of non-occupational origin, may have serious consequences and cause hardship to the workman. Some of those with disabilities assessed at less than $50 \%$ either continue their dusty occupation and get worse or leave on medical advice and receive no pension. One man in the pilot survey of this study was severely disabled after 16 years in the blow-room but he had spent 20 years in the spinning room. Another with less than 20 years in the card-room was getting rapidly worse but was not yet seriously disabled.

Some of the difficulties of diagnosing byssinosis for compensation could be overcome if workers at risk were medically examined at regular intervals, as is done in some dusty trades. Such a system of medical supervision would also indicate the mills which had high attack rates of byssinosis and which needed to pay special attention to dust control.

The coal-mining industry has a scheme whereby miners with less disabling stages of pneumoconiosis are encouraged to continue working under approved conditions (Hugh-Jones and Fletcher, 1951). A similar scheme might be developed for the cotton industry. Blow-rooms and card-rooms, in which only rayon fibres are processed, could be approved immediately since byssinosis is not known to occur in them. By further research it should be possible to assess the atmospheric concentration of dust which is safe and thus enable some mills spinning raw cotton to be approved. It is also necessary to know more about the natural history of the disease

TABLE 10

PREVALENCE OF BYSSINOSIS IN CARD-ROOM WORKERS AND SPINNERS AGED 40-59 IN SIX MILLS

\begin{tabular}{|c|c|c|c|c|c|c|c|c|c|c|c|c|}
\hline \multirow{3}{*}{\multicolumn{3}{|c|}{ Group }} & & & \multirow{3}{*}{ Sex } & \multirow{3}{*}{ Number } & \multirow{3}{*}{$\begin{array}{l}\text { Mean } \\
\text { Age }\end{array}$} & \multirow{3}{*}{$\begin{array}{c}\text { Mean } \\
\text { Exposure }\end{array}$} & \multicolumn{4}{|c|}{ Clinical Condition } \\
\hline & & & & & & & & & \multirow{2}{*}{ Normal } & \multicolumn{3}{|c|}{ Byssinosis } \\
\hline & & & & & & & & & & I & II & Total $\left(0_{0}\right)$ \\
\hline Card- and blow- & room workers & $\cdots$ & $\cdots$ & $\cdots$ & M. & 56 & $48 \cdot 2$ & $24 \cdot 8$ & 21 & 22 & 13 & 62 \\
\hline Card, draw, fran & ne, slubber tent & ters & $\cdots$ & $\cdots$ & $\mathrm{F}$. & 109 & $48 \cdot 8$ & $26 \cdot 8$ & 58 & 37 & 14 & 47 \\
\hline Intermediate anc & rover tenters & $\cdots$ & $\cdots$ & $\cdots$ & $\mathrm{F}$. & 109 & $48 \cdot 4$ & $27 \cdot 3$ & 84 & 17 & 8 & 23 \\
\hline Mule spinners & $\cdots$ & $\cdots$ & $\cdots$ & $\cdots$ & M. & 62 & $49 \cdot 6$ & $29 \cdot 0$ & 55 & 5 & 2 & 11 \\
\hline Ring spinners & $\cdots$ & . & $\cdots$ & . & $\mathrm{F}$ & 61 & $48 \cdot 2$ & $28 \cdot 2$ & 59 & 1 & 1 & 3 \\
\hline
\end{tabular}


and in particular its course in those who have had definite symptoms but who have been removed from further dust exposure.

All but three of the 28 mills studied were spinning the coarser grades of cotton * which account for $92 \%$ by weight of the yarn produced in the United Kingdom (Cotton Board, 1954). Thus they are likely as a group to be fairly typical of conditions in all cotton mills with the exception of the smaller number spinning the fine counts and in which it is thought that there is a lower prevalence of byssinosis. Accurate estimates of prevalence in relation to coarseness of cotton spun will be considered when it has been possible to investigate a full range of mills. The 28 mills in this study employed 3,933 men and 6,624 women of all ages, excluding office workers : $23.4 \%$ of the men and $33.4 \%$ of the women worked in the cotton blow- or card-rooms and were exposed to the risk of developing disabling byssinosis. There is no doubt that in spite of the active efforts to control dust, byssinosis is a major problem in the card-rooms of this type of spinning mill.

The components of card-room dust which may contain the causative agent of byssinosis are the fly, consisting of short pieces of broken fibre, fine dust derived from dried plant debris, bacteria, and moulds. Prausnitz (1936) suggested that the soluble protein fraction of the fine cotton dust was the cause of the disease. But this has not been supported by the recent work of Cayton, Furness, and Maitland (1952), who did skin testing with various extracts.

The epidemiological pattern of prevalence being inversely related to the distance of working groups from the carding engines suggests a new approach to the study of byssinosis, namely to investigate the relationship between concentrations of the various types of dust and prevalence in mills with stable populations. This study now started may help in isolating the fraction of dust causing the disease. At least it should indicate a maximum allowable concentration of dust which would give the cotton industry a target for dust suppression and would be a valuable step towards preventing byssinosis and enabling the disabled men to work under approved conditions.

\section{SUMMARY}

One hundred and ninety male card- and blowroom workers aged 40 to 59 years from 28 mills spinning the coarser grades of cotton, and 88 men of the same age from two engineering factories were

* That is, counts below 56; the count is the number of hanks of $840 \mathrm{yd}$. in $1 \mathrm{lb}$. of cotton. examined clinically and radiologically for respiratory disease.

One hundred and fifteen $(60 \%)$ of the cotton workers had symptoms of byssinosis characterized by tightness of the chest and breathlessness on Mondays. Respiratory disability was assessed by the severity of tightness of the chest and dyspnoea and the volume of gas expelled during the first $0.75 \mathrm{sec}$. of a forced expiration. Twenty-six (14\%) cotton workers were seriously disabled (eight have since received disability pensions) and 12 others were not so seriously disabled but appeared to be getting progressively worse. Of the controls, only four $(4.5 \%)$, three of whom had bronchitis, showed any serious degree of respiratory disability.

Subsequently, 218 women card-room workers, 61 ring spinners, and 62 mule spinners from six mills were examined in less detail than the men; seven mule spinners and two ring spinners had symptoms of byssinosis. The prevalence of byssinosis was inversely related to the distance of workers from the carding engines. This epidemiological finding may help to isolate the fraction of dust causing the disease and to establish maximum allowable concentrations of dust in card-rooms. Of all the employees in the 28 mills, $23 \%$ of the men and $33 \%$ of the women were exposed to the risk of developing disabling byssinosis.

The clinical differences between chronic bronchitis and byssinosis are discussed. It is probable that the extent of byssinosis has been obscured by the high prevalence of chronic bronchitis in Lancashire.

We should like to thank the many employers, mill managers, welfare officers, Trade Union representatives, factory inspectors, and workers whose cooperation made this study possible. We acknowledge our gratitude to Mr. W. G. Clarke and his team who so successfully toured the mills and factories with the mobile $x$-ray van under exceptionally severe weather conditions, and to the Department of Medical Illustration at the Manchester Royal Infirmary for preparing Figs. 1 and 3. We are grateful for the help and valuable criticism we received from our colleagues. One of us (R. S. F. S.) is grateful to the Medical Research Council for a grant to study byssinosis.

\section{REFERENCES}

Bernstein, L., and Kazantzis, G. (1954). Thorax, 9, 326

Cayton, H. R., Furness, G., and Maitland, H. B. (1952). British Journal of Industrial Medicine, 9, 186.

Cochrane, A. L. (1951). In The Application of Scientific Methods to Industrial and Service Medicine, p. 97. Medical Research Council. H.M.S.O., London.

Collis, E. L. (1909). Annual Report of Chief Inspector of Factories for 1908 , p. 203. H.M.S.O., London.

Cotton Board (1954). Quart. Statist. Rev., 36, 3.

Drummond, D. G., Hamlin, M., Donoghue, J. K., and Brownsett, F. (1954). British Journal of Industrial Medicine, 11, 151. 
Dunn, J. Shaw, and Sheehan, H. L. (1932). Report of the Departmental Committee on Dust in Card Rooms in the Cotton Industry, Appendix III Home Office, London.

Gaensler, E. A. (1951). Science, 114, 444.

Goodman, N., Lane, R. E., and Rampling, S. B. (1953). Brit. med. J., $2,237$.

Greenhow, E. H. (1861). Third Report of the Medical Officer of the Privy Council, 1860. Appendix VI.

Hill, A. Bradford (1930). Rep. industr. Hlth Res. Board, Lond., No. 59

Home Office (1932). Report of the Departmental Committee on Dust in Card Rooms in the Cotton Industry. H.M.S.O., London. (1939). Report of the Departmental Committee on Compensation for Card Room Workers. H.M.S.O., London.

Hugh-Jones, P., and Fletcher, C. M. (1951). The Social Consequences of Pneumoconiosis among Coal-miners in South Wales. H.M.S.O., London.
Kennedy, M. C. S. (1953). Thorax, 8, 73.

Leach, J. (1863). Lancet, 2, 648.

Ministry of National Insurance (1948). Statutory Instruments No. 2723 : Byssinosis Regulations.

Ministry of Pensions and National Insurance (1952-54). Annual Reports for 1951,1952 and 1953 . Cmds. 8635, 8882, and 9159. H.M.S.O. London.

Prausnitz, C. (1936). Investigations on Respiratory Dust Disease in Operatives in the Cotton Industry. M.R.C. Spec. Rep. in Operatives in the Cotton Indust

Registrar-General (1923). Supplement to 75th Annual Report for England and Wales 1910-12, Part IV. H.M.S.O., London.

Schilling, R. S. F., Goodman, N., and O'Sullivan, J.' G. (1952). British Journal of Industrial Medicine, 9, 146.

Hughes, J. P. W., and Dingwall-Fordyce, I. (1955). Brit. med. J., 1, 65 .

Tiffeneau, R., Bousser, J., and Drutel P. (1949). Paris méd. 39, 543.

\section{A PPENDIX I}

Examples of the histories of men with byssinosis and chronic bronchitis are given below.

\section{Byssinosis Grade I}

Case 1.-H. W. (203), a stripper and grinder, aged 45 years, had worked in the card-room for 25 years. He gave no history of any other chest illness. At about 3 p.m. on Mondays he noticed that he was slightly short of breath and that his chest felt tight. He had little appetite on Monday evenings. His chest began to feel better at about 11 p.m. On Tuesdays and other working days he was unaffected. He first noticed these symptoms on Mondays about 15 years ago, and they were not getting any worse. The heart and chest revealed no abnormal physical signs. Blood pressure was $125 / 85 \mathrm{~mm}$. Hg, M.V.V. 114 1./min., and radiographs normal.

\section{Byssinosis Grade II}

Case 2.-E. W. (286), a carder, aged 49 years, had worked for six years as a carder and previously for 24 years either as a blow-room worker or as a stripper and grinder. He had no history of any other chest illness. At about 10 a.m. on Mondays he felt a little tight on the chest and noticed that he was breathing slightly more quickly. He got worse as the day went on. By 4 p.m. he felt absolutely done-up and on Mondays it took him 10 minutes, which was at least twice the usual time, to walk 300 yards to his home. He had little appetite and never went out on Mondays. He felt better when he got up on Tuesday mornings, but his chest was not really normal until Thursdays. He had a dry cough which troubled him every night, except when he was on holiday. He first noticed these symptoms seven years ago. His complaint had definitely got worse in the last 12 months. His heart was normal. Coarse rhonchi were heard in the left axillary region by both observers. Blood pressure was $140 / 95 \mathrm{~mm}$. Hg, M.V.V. 85 1./min., and radiographs normal.
Disabling Byssinosis with Less than 20 Years' Exposure

Case 3.-O. A. (2), a blow-room worker, aged 50, had worked for a total of 17 years in card- and blowrooms. He worked in the spinning room from the age of 12 to 32 years. He gave no history of chest illness. About five years ago he noticed chest tightness and breathlessness on Mondays. He had got progressively worse and now had symptoms on every working day. He was permanently short of breath (dyspnoea grade 3 ). He had a dry cough. Generalized rhonchi in the chest were heard by both observers. The heart was normal and blood pressure was $125 / 90 \mathrm{~mm}$. $\mathrm{Hg}$.

\section{Chronic Bronchitis without Byssinosis}

Case 4.-G. W. (224), a blow-room man, aged 48 years, worked for 12 years in broken periods as a stripper and grinder and blow-room man. He gave a history of bronchitis, aged 20, at the time of going into the card-room, and of pneumonia when aged 32 . His breathing was affected by cotton dust when he first entered the card-room. It had never been worse on a Monday than on any other day, but cotton dust, like other dusts, made him cough and wheeze. He had a cough with sputum in the summer and winter. He had some effort intolerance and generalized rhonchi in the chest. Blood pressure was $130 / 80 \mathrm{~mm}$. Hg, M.V.V. $54 \mathrm{l} . / \mathrm{min}$., and radiographs were normal.

Case 5.-H. A. (58), a blow-room man, aged 44 years, had worked for 26 years in the cotton chamber and blow-room. He gave a history of having had bronchitis three to four years before. He had no symptoms of chest tightness on Mondays. He had an early morning cough with sputum, which was made worse when he did a dusty job such as taking the dirt out of the machine. He had no effort intolerance. Blood pressure was 144/92 mm. Hg, M.V.V. 89 1./min., and radiographs were normal. 


\section{A PPENDIX II}

THE PREVALENCE OF BYSSINOSIS IN ALL THE GROUPS OF WORKERS IN EACH OF THE SIX MILLS

\begin{tabular}{|c|c|c|c|c|c|c|c|c|c|c|c|c|c|c|c|}
\hline \multirow[t]{2}{*}{ Mill } & \multicolumn{3}{|c|}{$\begin{array}{l}\text { Male Card- and } \\
\text { Blow-room }\end{array}$} & \multicolumn{3}{|c|}{$\begin{array}{l}\text { Female Card } \\
\text { Tenters, etc. }\end{array}$} & \multicolumn{3}{|c|}{$\begin{array}{l}\text { Intermediate } \\
\text { Tenters, etc. }\end{array}$} & \multicolumn{3}{|c|}{ Mule Spinners } & \multicolumn{3}{|c|}{ Ring Spinners } \\
\hline & $\mathbf{N}$ & $\mathbf{I}$ & II & $\mathbf{N}$ & I & II & $\mathbf{N}$ & I & II & $\mathbf{N}$ & $\mathbf{I}$ & II & $\mathbf{N}$ & $\mathbf{I}$ & II \\
\hline $\mathbf{A}$ & 2 & 3 & 1 & 4 & 7 & 5 & 4 & 2 & 1 & 7 & 2 & 1 & 7 & 1 & 1 \\
\hline B & 3 & 1 & 1 & 7 & 6 & 1 & 17 & 2 & 2 & 30 & $\mathbf{0}$ & 1 & 16 & 0 & 0 \\
\hline $\mathrm{C}$ & 9 & 3 & 1 & 26 & 4 & 0 & 31 & 2 & 0 & \multicolumn{3}{|c|}{ None } & \multicolumn{3}{|c|}{ Not examined } \\
\hline D & 4 & 4 & 3 & 9 & 6 & 4 & 7 & 3 & 2 & \multicolumn{3}{|c|}{ None } & 14 & 0 & 0 \\
\hline $\mathbf{E}$ & 2 & 8 & 5 & 6 & 4 & 2 & 16 & 3 & $\mathbf{0}$ & \multicolumn{3}{|c|}{ None } & 16 & 0 & $\mathbf{0}$ \\
\hline $\mathbf{F}$ & 1 & 3 & 2 & 6 & 10 & 2 & 9 & 5 & 3 & 18 & 3 & 0 & 6 & 0 & 0 \\
\hline \multirow[t]{2}{*}{ Total } & 21 & 22 & 13 & 58 & 37 & 14 & 84 & 17 & 8 & 55 & 5 & 2 & 59 & 1 & 1 \\
\hline & $38 \%$ & $39 \%$ & $23 \%$ & $53 \%$ & $34 \%$ & $13 \%$ & $77 \%$ & $16 \%$ & $7 \%$ & $89 \%$ & $9 \%$ & $3 \%$ & $97 \%$ & $2 \%$ & $2 \%$ \\
\hline
\end{tabular}

